\title{
ASSESSMENT OF DURABILITY AND RELIABILITY OF ET41 SERIES LOCOMOTIVE WHEELS BASED ON LABORATORY TESTS
}

\author{
Mirosław WITASZEK \\ Silesian University of Technology, Department of Automotive Vehicle Service, \\ Faculty of Transport, Katowice, Poland, miroslaw.witaszek@polsl.pl
}

Abstract

The article presents the method of determination of life and reliability of rail vehicles wheels on the basis of the wear model developed on the basis of laboratory tests results. The method allowed quantitative assessment of the impact of various factors on the life of the wheels due to flange and tread wear. It was stated that the most significant impact on life resulting from the flange wear is exerted by the share of curves in track length, whereas life due to tread wear - longitudinal creepage of the tread with regard to the rail. The reliability assessment was performed using the Monte Carlo method. It allows to take into account randomness of both interaction conditions and the wear process. The determined reliability was described by the Weibull's distribution. The calculations were made for the ET41 series electrical freight locomotives. The method presented in this work can be suitable for preparation of schedules of wheel repairs and thus contribute to the increase of ride safety and comfort and therefore to the decrease of the costs of maintenance of the rail vehicles.

\section{Keywords: rail wheels, durability, reliability, wear model \\ OCENA TRWAŁOŚCI I NIEZAWODNOŚCI KÓŁ LOKOMOTYW SERII ET41 NA PODSTAWIE BADAŃ LABORATORYJNYCH}

\section{Streszczenie}

Artykuł przedstawia metodę określania trwałości i niezawodności kół pojazdów szynowych w oparciu o model zużycia opracowany na podstawie badań laboratoryjnych. Umożliwiła ona ilościową ocenę wpływu różnych czynników na trwałość kół, ze względu na zużycie obrzeża i powierzchni tocznej. Stwierdzono, że najistotniejszy wpływ na trwałość, wynikającą ze zużycia obrzeża, wywiera udział łuków w długości toru, natomiast na tę wywołaną zużyciem powierzchni tocznej - poślizg wzdłużny tej powierzchni względem szyny. Do oceny niezawodności wykorzystano metodę Monte Carlo. Pozwala to na uwzględnienie losowości zarówno warunków współpracy, jak i samego procesu zużycia. Wyznaczoną niezawodność opisano rozkładem Weibulla. Obliczenia przeprowadzono dla towarowych lokomotyw elektrycznych serii ET41. Metoda zaprezentowana w niniejszej pracy może być przydatna przy sporządzaniu harmonogramu napraw kół i dzięki temu przyczynić się do poprawy bezpieczeństwa i komfortu jazdy, a także do obniżenia kosztów utrzymania pojazdów szynowych.

Słowa kluczowe: koła kolejowe, trwałość, niezawodność, model zużycia

\section{INTRODUCTION}

In recent years one can observe the development of rail transport in Poland [10]. One of the reasons for this development are ecological considerations [18]. The factors that determine how competitive the railways are depend on transport time, costs, and comfort. They, in turn, depend directly on the technical condition of railroad wheels and rails [17, 24].

Apart form the time, cost or comfort, the safety of rail transport depends to a large extent on the aforementioned technical condition. This condition deteriorates as a result of wear and rolling contact fatigue $[4,7,21]$. The rolling contact fatigue plays an important role in the case of high-speed railroads, high usage of trains in large cities, and heavy haul freight railways, especially when increased axle loading acts on the latter, e.g. up to $30 \mathrm{t}[11,12,16]$. However, as reported in [8, 20], intensive wear may also occur in the case of wheels of high-speed vehicles or heavy haul freight railways. Hollow wear of wheel tread is the main problem of railways in desert areas [5]. For the time being, there are neither high-speed nor heavy haul freight railways in Poland, so the main factor limiting the durability of wheels and tracks in Poland is their wear.

Worn or damaged wheels and tracks undergo either replacement or regeneration. This results in high costs. For example, as mentioned in [14], the annual maintenance cost of each meter of track 
which serves as a passage for trains that weigh 12 million gross tons amounts to USD \$ 54 .

The method of preventing rolling contact fatigue of the tracks is grinding; however, it is expensive and can lead to reduced rail life [16, 20] when performed excessively. There are also works conducted aimed at increasing the resistance of steel to wear and rolling contact fatigue of tracks, e.g. through the selection of material or heat treatment [3, 24, 28, 29]. What also affects wheel and track wear is the design of the suspension system of bogie trucks. For instance, the use of rail vehicles with a special bogie design for heavy goods transport can ensure a significant reduction in flange wear, compared to the high flange wear rates of conventional bogies [20].

Wheel and track wear occurs when rollingsliding friction takes place. There are three varieties of wear regimes: mild wear, severe wear and catastrophic wear $[25,26]$. The dominant mechanism of mild wear is oxidation when the material loss is negligible. Catastrophic wear consists in spalling and fatigue cracking in the subsurface [25]. Spalling occurs when, as a result of the wheel sliding along a track, enough heat is released in the contact zone to heat up the surface to over $730^{\circ} \mathrm{C}$ for at least a few seconds [26]. In this case, a transformation of pearlite into the fragile martensite occurs. Another possible mechanism of wear is shelling. The process occurs when the wheel's rolling surface heats up to over $300^{\circ} \mathrm{C}$ for at least a few minutes. This weakens the material, in which the contact stresses created by the wheel-rail interaction can initiate the formation of microcracks [26]. Their formation may be facilitated by contamination of contact surfaces, such as water, sand or dust [26]. As a result of both spalling and shelling, shallow craters are formed on the surface from which flake-like wear debris is removed [26]. During severe wear, the mechanism changes from oxidation to flaking and fatigue cracking [25]. Apart from the above-mentioned wear mechanisms, adhesive and abrasive wear occurs $[2,26]$.

Since many rail vehicles are equipped with shoe brakes, the question of how their performance affects the wear of wheel tread is relevant. As shown in the study [15], only a small amount of cast iron from brake pads is transferred onto the wheel tread. Most of it is quickly removed when the wheel and track interact. This has no noticeable effect on wheel wear.

\section{THE WEAR MODEL}

The prediction of wheel and rail wear allows for proper planning of maintenance interventions; as a consequence, it can reduce its costs, improve ride comfort, and even contribute to the prevention of derailment [17, 19].

For predicting wheel or track wear, the Archard model is used, described by the equation $[13,17$, 21]:

$$
Z_{V}=K \cdot \frac{F_{N} \cdot l}{H_{1}},
$$

where $Z_{V}$ is the volume loss, $K$ is the specific wear rate, $F_{N}$ is the normal force, $l$ is the sliding distance, $H_{1}$ is the material hardness.

In the paper [4] it was found that not only the material hardness of the component which undergoes wear affects its wear but also the hardness ratio of both interacting components, e.g. wheel/rail hardness ratio.

Other models used for wheel and track wear prediction are based on an energy approach. In these models, it is assumed that wear constitutes a function of the dissipated energy by friction in contact $[17,20]$. The model used in the work [20] is described by the equation:

$$
Z=k \cdot \frac{\left(T_{x} \cdot s_{x}+T_{y} \cdot s_{y}\right) \cdot l_{P}}{A \cdot \rho},
$$

where: $Z$ is the wear depth, $k$ is the wear coefficient, $T_{x}$ and $T_{y}$ are the tangential creep forces in the longitudinal and lateral directions respectively, $s_{x}$ and $s_{y}-$ are the slippages in the longitudinal and lateral directions respectively, $l_{P}$ is the load path length of a particle traveling in the contact patch, $A$ is the contact area, $\rho$ is the material density.

In this model, the wear coefficient $k$ is dependent on the properties of the material and the wear regime. For mild wear, it is $4.5 \cdot 10^{-7} \mathrm{~g} \cdot \mathrm{N}^{-1} \cdot \mathrm{m}^{-1}$; whereas for severe wear, it is $1.25 \cdot 10^{-7} \mathrm{~g}^{\cdot} \mathrm{N}^{-1} \cdot \mathrm{m}^{-1}$ [20]. For different materials the transition from one wear regime to another takes place under different conditions. With this model, the so-called wear maps [20] are used to describe the dependence of wear on pressure and sliding velocity. As indicated in the study [20], the use of such a model is not generally applicable.

In the work [19], artificial neural networks were used to predict wheel and track wear. The results of 87 laboratory tests for lateral creep during rollingfriction with lateral creep caused by yaw of roller samples whose contact surfaces were replicas of the wheel and rail profile on a scale of 1:3 were used to train and test these networks. The factors needed to predict wear were as follows: load, yaw angle, speed, and wheel/rail profiles as well as the first and second derivative of wheel/rail profiles [19]. As a result of the prediction, one value of wear depth was established for each set of interacting conditions. The experience the author of the present work had personally indicates that the results of laboratory wear tests, even under constant conditions, show a certain scatter, not only during the running-in period, but also after its completion. For the purpose of assessing durability and reliability, it is necessary to take into account this scatter. In the work [13], the scatter is taken into account thanks to the application of stochastic modelling of variable operating conditions, using the normal distribution. This requirement is met by the model developed in the present article. 
In order to develop the wear model, it was necessary to specify the input values. These include the interacting conditions that affect wear, which are as follows [17]: contact pressure, slippage ratio (also referred to as creep ratio), and linear speed. The latter is significant for high-speed railways [4]. Since the maximum speed of ET41 locomotives is $125 \mathrm{~km} / \mathrm{h}$, this factor is not taken into account in the model. Whereas the impact of speed on the centrifugal force acting on the vehicle on a curve and thus on lateral forces acting on wheel flanges was taken into account.

The determination of wheel-rail contact pressure and slippage is of great importance for both wheel and track maintenance engineers and railway vehicle dynamics researchers [27]. Knowing the stresses at this contact allows not only to assess the wear of the wheel profile and rail head, but also to determine their life and profiles of wheel and rail optimization [27]. The forces occurring in the wheel-rail contact derive from rolling and sliding, and have vertical, longitudinal and lateral components [30]. The vertical components result, among other things, from the axle load, whereas the lateral components arise from the flanging of wheel against the outer rail on curves and the centrifugal force [30]. Measuring these forces poses a serious challenge for researchers $[23,30]$.

The methods that are often used to determine wheel-rail contact stresses are the finite element method or the boundary element method; however, as they require a large number of calculations, their use is limited [27]. Therefore, the authors of [13, 27] recommend Hertz's and Kalker's equations for stress analysis in this contact.

In addition to the above mentioned values, the wear is dependent on the material properties. According to the information given in the works [4, 13, 17], the wheel and rail hardness was selected. Since pearlitic steels constitute the most commonly used material for wheels and rails in most countries $[7,8,22]$, the wear model in the present work was developed for exactly these materials.

As mentioned above, wear models may take into account different wear regimes, such as mild and severe wear. This is justified when sudden changes in wear rate occur under certain conditions. Provided in the study [25], the figures depicting the dependence of wear on the interacting conditions do not indicate the occurrence of such changes, despite the existence of different wear regimes. Therefore, the model presented in this paper is described by one equation. Its mathematical form is the same as in the previous paper [1], namely:

$$
\frac{Z}{l}=c_{0} \cdot\left(\frac{p_{0}}{H_{1}}\right)^{c_{1}} \cdot s^{c_{2}} \cdot\left(\frac{H_{2}}{H_{1}}\right)^{c_{3}},
$$

where $Z$ is the wear depth in $\mathrm{mm}, p_{0}$ is the maximum Hertzian pressure in $\mathrm{MPa}, l$ is the sliding distance in mm, $s$ is the slippage, $H_{1}$ and $H_{2}$ are the hardness of mating elements, considered and cooperating respectively in $\mathrm{HB}$.

The numerical coefficients of the model were determined by performing a regression of the laboratory results of wear tests for rolling-friction with slippage. For this purpose, more than twice as many tests were used compared to the work [1], obtained for a larger amount of steel used in production of wheels and rails as well as for a wider range of interaction conditions. While comparing with the previous model, the advantage of the present one is a significantly higher accuracy. It allows for more precise prediction of wear as well as determination of wheel and rail durability and reliability.

\section{EXPERIMENTAL DETAILS}

The tests covered five tyre steels of B6, P54 and P60 grades and four rail steels of 900A and 900ACrV grades. The chemical composition and hardness of the tested materials are provided in table 1. Laboratory wear tests were conducted on an Amsler testing machine (fig. 1).

Roller samples were mounted on two rolling shafts. The rotational speed of one of them (the bottom one) was 1.104 times higher than the other one. Hence, with equal diameters of the rollers, the slippage is 0.104 (or 10.4\%). Other values of the slippage were obtained by appropriate selection of the diameter of the samples. Its value for the wheel sample placed on the shaft with higher rotational speed was determined from the formula [17]:

$$
s_{W}=\frac{\omega_{W} \cdot R_{W S}-\omega_{R} \cdot R_{R S}}{\omega_{W} \cdot R_{W S}},
$$

Table 1. Chemical composition and hardness of tested tyre and rail steels

\begin{tabular}{|c|c|c|c|c|c|c|c|c|c|c|c|c|c|c|}
\hline \multirow{2}{*}{$№$} & \multirow{2}{*}{ Steel grade } & \multicolumn{10}{|c|}{ Chemical composition (wt\%) } & \multicolumn{1}{c|}{ Hardness, } \\
\cline { 3 - 15 } & & $\mathrm{C}$ & $\mathrm{Mn}$ & $\mathrm{Si}$ & $\mathrm{P}$ & $\mathrm{S}$ & $\mathrm{Cr}$ & $\mathrm{Ni}$ & $\mathrm{Cu}$ & $\mathrm{Mo}$ & $\mathrm{Al}$ & $\mathrm{V}$ & $\mathrm{HB}$ \\
\hline 1 & $\mathrm{~B} 6$ & 0,61 & 0,82 & 0,34 & 0,010 & 0,004 & 0,02 & 0,01 & 0,03 & 0,001 & 0,031 & 0,001 & 285 \\
\hline 2 & $\mathrm{P} 54$ & 0,56 & 0,69 & 0,22 & 0,018 & 0,035 & - & - & - & - & - & - & 203 \\
\hline 3 & $\mathrm{P} 54$ & 0,53 & 0,73 & 0,22 & 0,016 & 0,004 & - & - & - & - & - & - & 292 \\
\hline 4 & $\mathrm{P} 60$ & 0,61 & 0,79 & 0,30 & 0,016 & 0,004 & - & - & - & - & - & - & 280 \\
\hline 5 & P60 & 0,61 & 0,76 & 0,29 & 0,017 & 0,006 & - & - & - & - & - & - & 203 \\
\hline 6 & $900 \mathrm{~A}$ & 0,74 & 1,09 & 0,29 & 0,015 & 0,015 & - & - & - & - & - & - & 294 \\
\hline 7 & $900 \mathrm{~A}$ & 0,70 & 1,09 & 0,29 & 0,016 & 0,016 & - & - & - & - & - & - & 243 \\
\hline 8 & $900 \mathrm{~A}$ & 0,73 & 1,10 & 0,30 & 0,024 & 0,015 & - & - & - & - & - & - & 278 \\
\hline 9 & $900 \mathrm{ACrV}$ & 0,77 & 1,14 & 0,36 & 0,017 & 0,015 & 0,26 & - & - & - & - & 0,051 & 375 \\
\hline
\end{tabular}




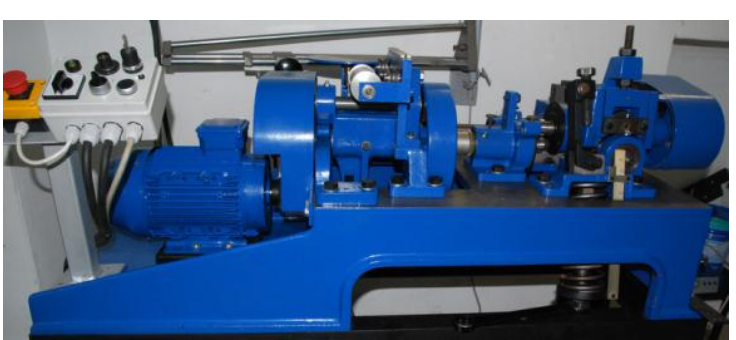

Fig. 1. Amsler testing machine

where $s_{W}$ is the slippage for a wheel sample, $\omega_{W}, \omega_{R}$ are the rotational speeds respectively for the wheel and rail samples, $R_{W S}, R_{R S}$ is the radius of sample, respectively from wheel and rail.

In order to facilitate model calculations, the slip was not expressed in $\%$ in further considerations. The tests were performed for slippages in the range from 0.002 to 0.137 . The second test parameter was the normal force applied by a spring. For the tests it was assumed within the range from $490.5 \mathrm{~N}$ to 1962 N (50 kgf - $200 \mathrm{kgf}$ ). During the tests, samples were periodically stopped, dismantled and weighed with an accuracy of $0.0001 \mathrm{~g}$ to determine wear. An example of the relationship between wear and the number of revolutions of the wheel sample is shown in Fig. 2.

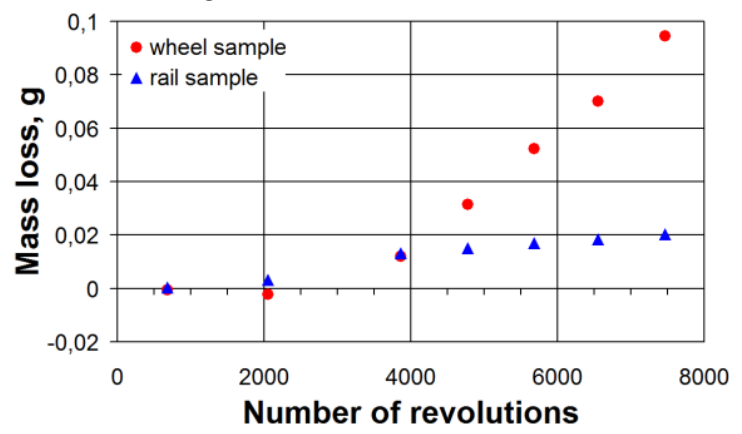

Fig. 2. The relation of mass loss vs. number of revolutions for the wheel and rail samples (steels № 2 and 7 in the table 1respectively) at the slippage of $0.03(3 \%)$ and maximum Hertzian pressure of $973 \mathrm{MPa}$

\section{RESULTS AND DISCUSSION}

\subsection{Wear rate}

In order to determine the numerical coefficients $c_{\mathrm{i}}$ of the wear model described by equation (3), the maximum Hertzian pressure and the sliding distance were determined for individual tests. The maximum Hertzian pressure was calculated from the formula [6]:

$$
p_{0}=0,418 \cdot \sqrt{\frac{F_{N} \cdot E}{2 b_{H} \cdot R_{Z}}}
$$

where: $p_{0}$ is the maximum Hertzian pressure in $\mathrm{MPa}, F_{N}$ is the normal force in N, $E$ is the Young's modulus of $2,1 \cdot 10^{5} \mathrm{MPa}, 2 b_{H}$ is the width of roller contact towards their axles in $\mathrm{mm}$ and $1 / R_{Z}=1 / R_{W S}+1 / R S_{R}$.

The following formula was used to calculate the sliding distance [1]:

$$
l=2 \cdot a_{H} \cdot n \cdot s,
$$

where $a_{H}$ is the semi axis of elastic contact ellipse or half the width of the rectangular area of this contact towards rolling, $N$ is the number of revolutions.

Since the elastic contact of the rollers is a rectangle, its width in the turning direction of $2 a_{H}$ was determined by dividing its area determined from the equation [6]:

$$
A=\frac{4 \cdot F_{N}}{\pi \cdot p_{0}}
$$

by the width of roller contact $2 b_{H}$.

As mentioned earlier, the coefficients $c_{\mathrm{i}}$ of the equation (3) were determined by regression of the 202 test results. They are presented in table 2 .

The accuracy of the approximation of the test results by the wear model was assessed using the square of the correlation coefficient. It is high and amounts to 0.89 , which made it possible to use the developed model to calculate the durability and reliability of railway wheels.

Table 2. The numerical coefficients of the wear model

\begin{tabular}{|c|c|c|}
\hline Coefficient & Average & $\begin{array}{c}\text { Standard } \\
\text { deviation }\end{array}$ \\
\hline $\ln c_{0}$ & -7.04 & 0.15 \\
\hline$c_{0}$ & $87.9 \cdot 10^{-5}$ & - \\
\hline$c_{1}$ & 1.24 & 0.10 \\
\hline$c_{2}$ & 1.038 & 0.028 \\
\hline$c_{3}$ & 1.12 & 0.24 \\
\hline
\end{tabular}

\subsection{Durability}

The life of railways wheels is determined as a mileage of a vehicle before reaching permissible wear. In case of flange wear, this durability is the mileage between reprofiling of wheels. Equation (3) allows to determine the durability of wheels and rails. Then, the wear depth of $Z$ is replaced with permissible wear $Z_{P}$ and sliding distance $l$ is calculated from the equation (3). Then it is converted to mileage $T$ of the wheel using the following formula [1]:

$$
T=\left(1-s_{W}\right) \cdot \frac{\pi \cdot D \cdot l}{2 \cdot a_{H} \cdot s}
$$

where $D$ is the tread of the wheel diameter, $s$ is the total slippage between wheel and rail, $s_{W}$ is the wheel longitudinal slippage in tread of the wheel, calculated from the formula [27]:

$$
s_{W}=\frac{\mathrm{v}_{2}-\mathrm{v}_{1}}{\mathrm{v}_{2}},
$$

where $\mathrm{v}_{1}$ is the travelling speed, $\mathrm{v}_{2}$ is the peripheral speed of a tread of a wheel.

Total slippage was determined from the formula [1]:

$$
s=\sqrt{\left(s_{W}+s_{S}\right)^{2}+s_{L}},
$$

where $s_{S}$ is the spin, $s_{L}$ - lateral slippage.

Spin was calculated from the formula [1]: 


$$
s_{S}=\frac{\Delta R_{W}}{R_{W}+\Delta R_{W}},
$$

where $R_{W}$ is the radius of wheel tread, $R_{W}+\Delta R_{W}$ is the wheel radius in the analysed point,

Lateral slippage is determined from the formula [1]:

$$
s_{L}=\operatorname{tg} \alpha
$$

where $\alpha$ is the yaw angle between wheel and rail.

Durability $T$ of wheels was calculated from the formula [1]:

$$
\begin{aligned}
& T=\left(1-s_{W}\right) \frac{1}{c^{\prime}{ }_{K}} \cdot \frac{\pi \cdot D \cdot Z_{P}}{2 a_{H} \cdot s \cdot c_{0}} . \\
& \cdot\left(\frac{p_{0}}{H B_{1}}\right)^{-c_{1}} \cdot s^{-c_{2}} \cdot\left(\frac{H B_{2}}{H B_{1}}\right)^{-c_{3}}
\end{aligned}
$$

where $c_{0}, c_{1}, c_{2}, c_{3}$ are the wear model coefficients given in the table $2, Z_{P}$ is the permissible wear, $c^{\prime}{ }_{K}$ is frequency coefficient of contact of the considered fragment of the wheel profile with the rail:

The wheel-rail contact frequency coefficient was calculated from the formulas [1]:

$$
\begin{gathered}
c^{\prime}{ }_{K}=\left\{\begin{array}{l}
c^{\prime}{ }_{K T} \text { for wheel tread } \\
c^{\prime}{ }_{K O} \text { for wheel flange }
\end{array}\right. \\
c^{\prime}{ }_{K T}=\left(1-c_{R}\right) \frac{2 b_{H}}{l_{Z}}, \\
c^{\prime}{ }_{K O}=0,25 \cdot c_{R},
\end{gathered}
$$

where $c_{R}$ is the share of curves in the length of the distance travelled by the vehicle, $2 b_{H}$ is the length of the contact ellipse axis in the direction parallel to the axis of the wheelset, $l_{Z}$ is the wheel tread profile length.

Works [13] and [20] present the share of straight and curved rails of various radiuses respectively for examples of two railways. The first one is a high-speed rail. A tangent track is $71.9 \%$ of its length. The radius of the curves present in the vicinity of a station is ca. $3,000 \mathrm{~m}$, and their share is $2 \%$. The radius of the remaining curves is from $7,000 \mathrm{~m}$ to more than $11,000 \mathrm{~m}$. The highest share is of the curves of the radius of $9,000 \mathrm{~m}(7.5 \%)$ and $7,000 \mathrm{~m}(6.7 \%)$. The superelevation applied is from $100 \mathrm{~mm}$ to $175 \mathrm{~mm}$ [13]. However, the latter serves the heavy freight transport. The straight (tangent) rail share in the total length of this line is $47.7 \%$. The railway line includes curves of the radius from $1,000 \mathrm{~m}$ to $5,000 \mathrm{~m}$, with the highest number of the curves with radius of $1,500 \mathrm{~m}(13.1 \%)$ and 2,000 m $(5.6 \%)$. The corresponding superelevation is from 1 $\mathrm{mm}$ to $30 \mathrm{~mm}$.

The forces acting between the wheel and the rail, needed to calculate the maximum Hertzian pressure in the model for the wheel tread, were calculated by dividing the vehicle weight by the number of wheels [1]. For the flange, these forces were determined from the Heumann model, which took into account the influence of the centrifugal force on the lateral forces [1]. Its coefficient of friction between the wheel and rail ranges from about 0.1 to 0.5 and its average value is 0.3 [13].

The dependence of the normal force acting between the flange of the attacking wheel (at the point where flange thickness is measured) and the outer rail of the curve from the curve radius and driving speed is presented in Figure 3.

It results from Figure 3 that the curve radius has the largest impact on the normal force between the flange of the attacking wheel and the side of rail head. The smaller the radius of the curve the larger the normal force on the attacking wheel. This rule is well known. In general the impact of speed is reverse as its increase causes the rise of the centrifugal force. This force is decreased thanks to using the mentioned superelevation of the track in curve, that is placement of the outer rail higher than the inner one. Therefore the values of the force calculated for different speeds in certain scope of curve radius are equal. The impact of curve radius and of the speed is the largest for the curves of small radius.

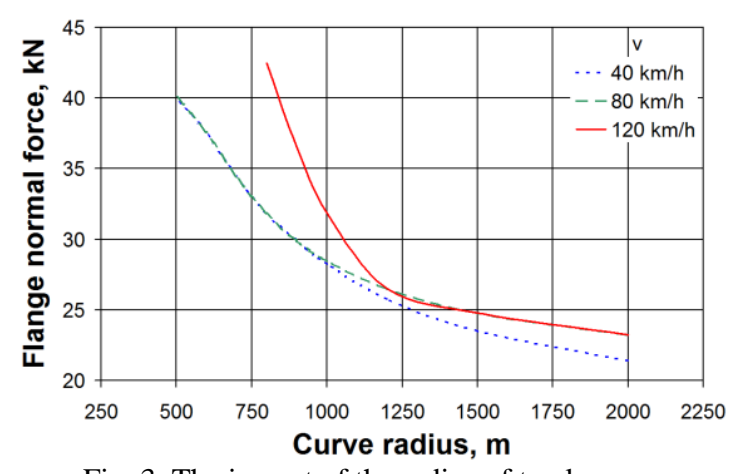

Fig. 3. The impact of the radius of track curve and of the driving speed of ET41 locomotive on the normal force between the flange of the attacking wheel and the gauge side of rail head for the index of equal friction 0.3

The wheel durability of the ET41 series locomotive was calculated from formula (13). It is an electric double locomotive. Each section's weight is $83.5 \mathrm{t}$. Its body is placed on two fourwheel trucks with $1,250 \mathrm{~mm}$ wheel tread diameter. The permissible wear values for the wheel tread and the flange were adopted on the basis of the Mt 11 instruction on geometric measurements of traction vehicle wheel sets of the Polish State Railways. They are respectively $8 \mathrm{~mm}$ (loss of the radius of the wheel tread) and $10.5 \mathrm{~mm}$ (reduction of the flange thickness). As a result of the calculations, the influence of various parameters on the durability of the wheels was determined.

Figures 4-11 presents dependency of average life of wheel tread and flanges from different parameters that characterize the track, the vehicle movement as well as the material of wheels and rails. The average life was calculated assuming in the equation (13) the average values of the $c_{\mathrm{i}}$ coefficients from Table 2. The share of curves $c_{R}$ equal to 0.35 was assumed for most calculations of life. 
Figures 4 and 5 present the dependency of the average wheel life due to tread wear (abbreviated to tread life) from its longitudinal creepage on the rail and hardness of the wheel $H_{W}$ and of the rail $H_{R}$. As it results from these Figures, this creepage has the dominant impact on the life of the wheels due to the tread wear. As it increases of the order of magnitude (from 0.002 to 0.02 ) life decreases by two orders of magnitude, which is caused by the increase of the intensity of wheels wear. The impact of the hardness of wheels and rails (in the presented scope) on the life of wheels is significantly lesser, whereas the increase of the hardness of wheels increases their life stronger than the decrease of hardness of rails of the same amount of HB units.

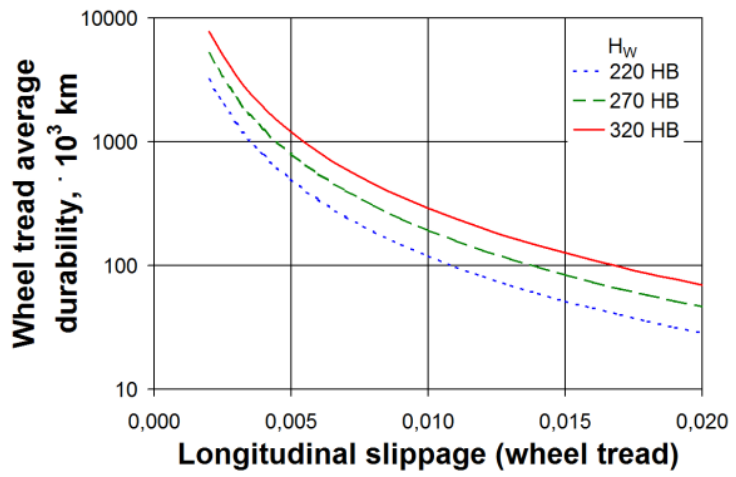

Fig. 4. The impact of longitudinal creepage on the tread and hardness of the wheel $\left(\mathrm{H}_{\mathrm{W}}\right)$ on the average life of the wheel due to wear in the wheel tread for the rail hardness $300 \mathrm{HB}$

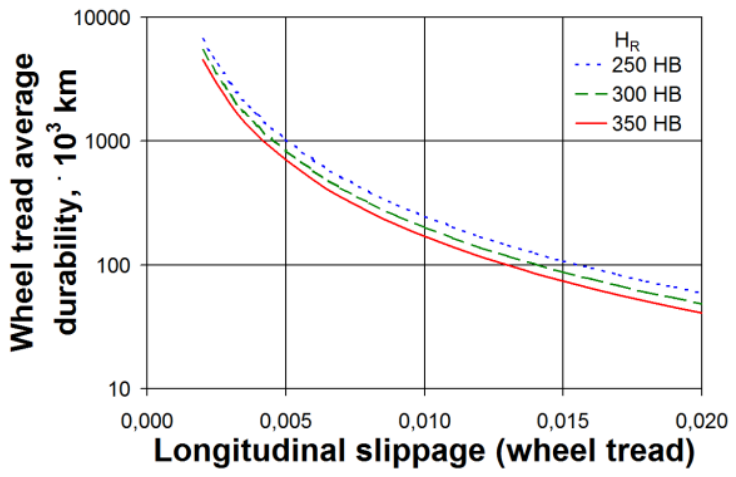

Fig. 5. The impact of longitudinal creepage on the tread and hardness of the rail $\left(\mathrm{H}_{\mathrm{R}}\right)$ on the average life of the wheel due to wear in the wheel tread for the rail hardness $275 \mathrm{HB}$

Since Figures 4 and 5 applied the logarithm scale on the life axis, which makes it difficult to assess the impact of hardness of both mating elements on the life of wheels, Figure 6 presents the impact of the material of wheels and rails for longitudinal creepage of 0.005 . It applied the linear scale on the life axis.

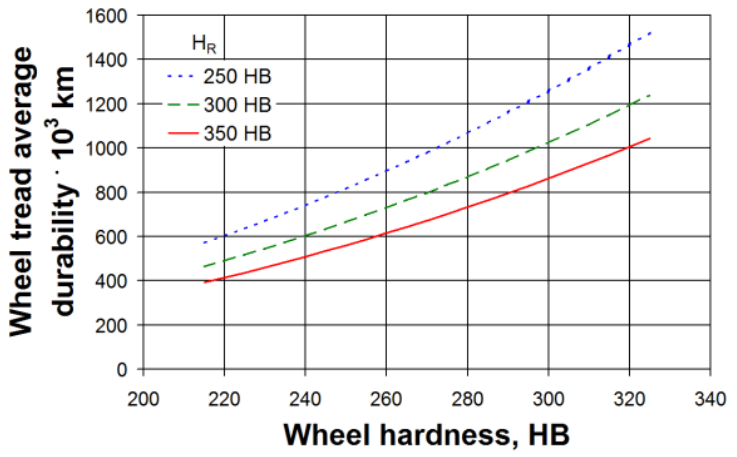

Fig. 6. The impact of the hardness of wheel and rail on the average life of wheels due to wear in the wheel tread for longitudinal creepage of the wheel tread equal to 0.005

It results from Figure 6 that the increase of hardness of wheel by $100 \mathrm{HB}$ increases their life by approximately 2.5 times, whereas the decrease of the hardness of rails also by $100 \mathrm{HB}$ decreases the life of wheels by approximately $50 \%$. This statement refers to the analysed scopes of hardness of wheels and rails.

Figure 7 presents the impact of longitudinal creepage on the tread and radius of the track curve on the average life of the wheels due to the flange wear (the so-called flange durability). It results from the Figure that this impact is significant. The increase of creepage by the order of magnitude (from 0.002 to 0.002) decreases life by approximately four times. Therefore it is not as significant as in the case of the wheel tread. The reason for this is the occurrence of large spin caused by the difference of the wheel radius on the tread surface and flange at the spot of thickness measurement. Thus the creepage of the flange against the side of rail head is larger by less than $0.02(2 \%)$ than in the case of tread of the wheel and rail. As a result by the increase of the creepage on the tread from 0.002 to 0.02 (i.e. from $0.2 \%$ to $2 \%$ ) the creepage on the flange increases approximately twice (Figure 8).

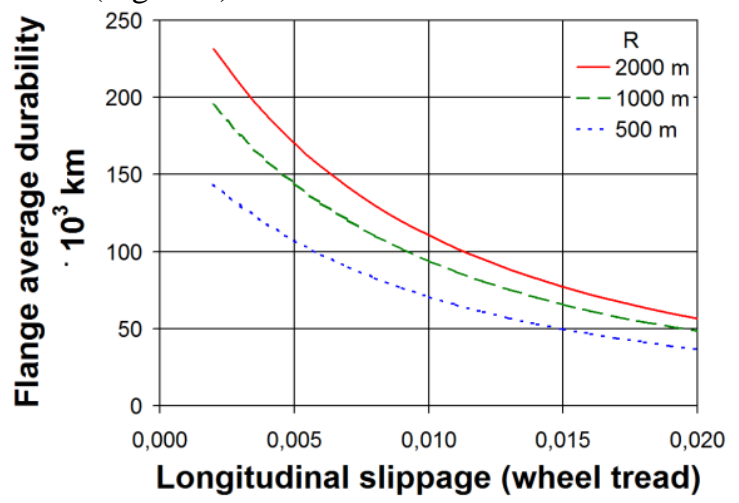

Fig. 7. The impact of longitudinal tread and curve radius $(\mathrm{R})$ on the average life of the wheels due do the wear of the flange for: the speed of $80 \mathrm{~km} / \mathrm{h}$, friction co-efficient 0.3 , hardness of the wheel $275 \mathrm{HB}$ and hardness of the rail $300 \mathrm{HB}$ 


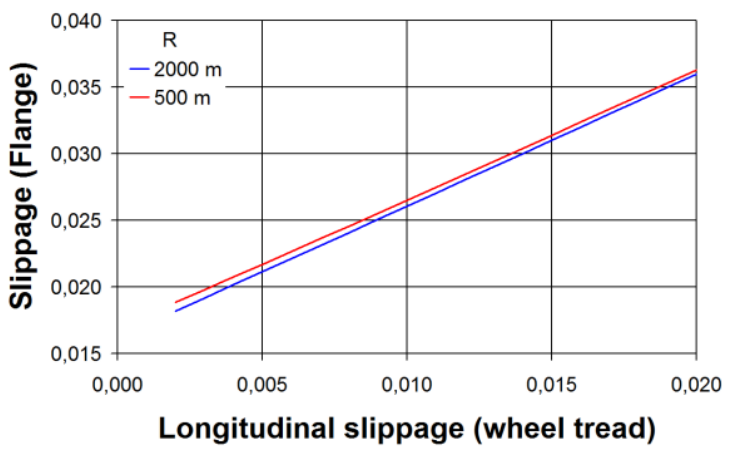

Fig. 8. The impact of longitudinal creepage in the tread of a wheel and curve radius on the total creepage of the flange against the side of the rail head at the spot of thickness measurement

The next factor for which the impact on the life of the flange was analysed is the friction coefficient between the wheel tread and the rail. Its increase causes the rise of the force between the flange and the rail, just as of the rate of the flange wear. It causes the decrease of life. The opposite effect is caused by the increase of the radius of the track curve, it is smaller but significant.

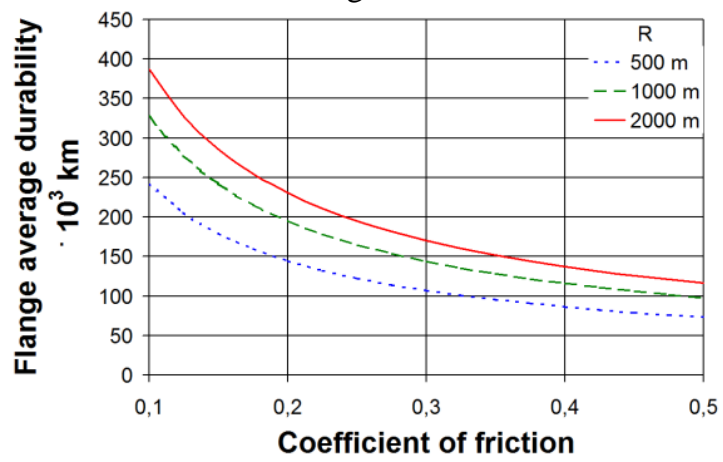

Fig. 9. The impact of the friction coefficient between the wheel tread and the track and curve radius $(\mathrm{R})$ on the average life of the wheels due to the wear of the flange for: creepage 0.005 , speed $80 \mathrm{~km} / \mathrm{h}$, hardness of the wheel $275 \mathrm{HB}$ and hardness of the rail $300 \mathrm{HB}$

Figure 10 presents the dependency of the average wheels life due to the flange wear on the share of curves in the track length and the radius of the curve. As it results from the Figure the share has a decisive role in the calculated life. Its increase causes the decrease of life, in particular in the scope of small values. The impact of the curve radius on life is apparently smaller. Therefore the usage of locomotive on the railroads with small number of curves results in the significant extension of life of the flanges. In such case the necessity of reprofiling of wheels may be decided by the tread wear. Whereas the life of flanges of the wheels of locomotives used on the winding mountain railroads is small.

The dependence of the flange life on the curve radius and driving speed is presented in Figure 11. It is strictly connected with the dependency of the normal force on the flange from the a.m. parameters. The greater the force the larger the Hertzian pressure and so is the intensity of the wear. The increase of the wear intensity decreases the life.

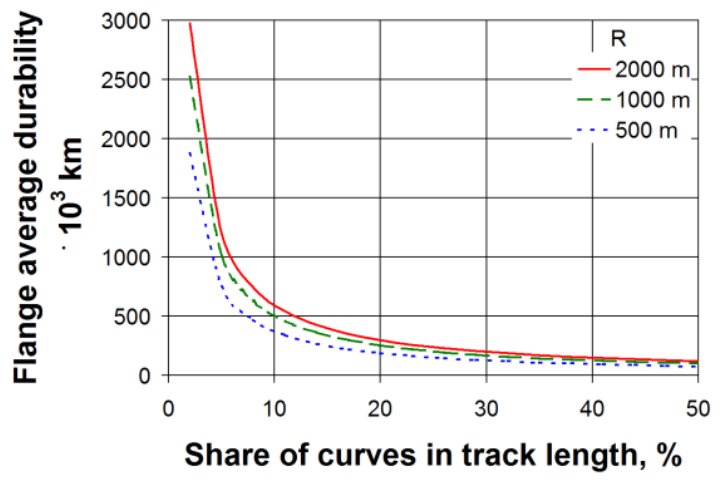

Fig. 10. The impact of the share of curves in the length of the track and curve radius $R$ on the average life of the wheels due to the flange wear for: creepage 0.005 , speed 80 $\mathrm{km} / \mathrm{h}$, friction coefficient 0.3 , hardness of the wheel $275 \mathrm{HB}$ and hardness of the rail 300 $\mathrm{HB}$

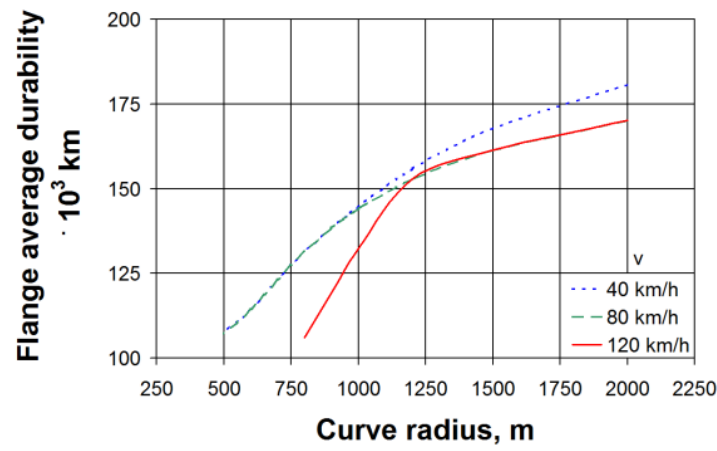

Fig. 11. The influence of curve radius and the speed of driving on the average life of the wheels due to flange wear for longitudinal slippage of the tread 0.0005 , friction coefficient 0.3 , wheel hardness $275 \mathrm{HB}$ and rail hardness $300 \mathrm{HB}$

The dependence of the wheel life due to flange wear on the hardness of the wheel and rail is presented in Figure 12. Similarly as in the case of the tread the increase of the wheel hardness increases its life and the hardness of the rail has the opposite effect. The changes are however smaller as they occur by lesser pressure and larger creepage.

\subsection{Reliability}

The life of the wheels of real vehicles is a random variable. Its distribution is described by among others the lifetime distribution function and the reliability function (survival function). For the purpose of their determination it was necessary to obtain a significant number of results of calculations of wheels life. They were received using the Monte Carlo method. It consisted in generation of 1000 sets of pseudorandom numbers corresponding to 1000 sets of coefficients $c_{0}, c_{1}, c_{2}$ and $c_{3}$ in equation (13), which served for calculation of life. Since by statistical testing of 
significance of these coefficients one uses the $t$ Student or normal distributions (depending on the amount of measurements and the estimated regression coefficients), it was assumed that the coefficients have the normal distributions. The number of tests used for determination of the wear model allowed it. The parameters for the normal distribution was assumed according to Table 2.

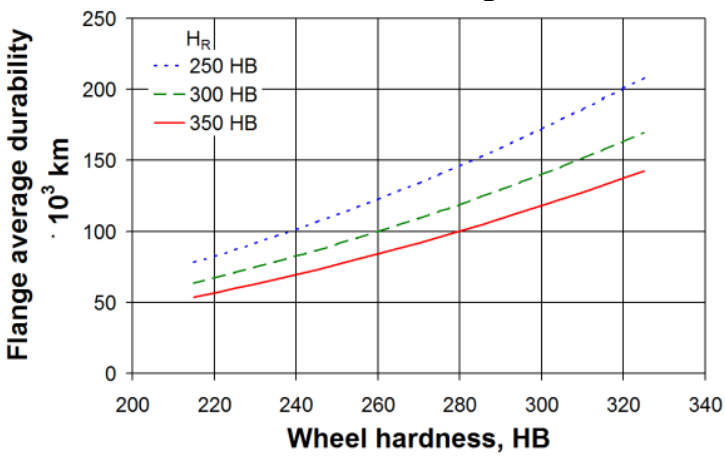

Fig. 12. The impact of the hardness of wheel and rail on the life of the wheels due to flange wear at the longitudinal creepage of the tread 0.005 , curve radius $600 \mathrm{~m}$, speed $80 \mathrm{~km} / \mathrm{h}$ and friction coefficient 0.3

The generated regression coefficients were used for calculation of 1000 durabilities of the wheels due to tread and flange wear. The remaining quantities occurring in the formula (13) were assumed as permanent: tread creepage 0.005 , friction coefficient 0.3 , driving speed $80 \mathrm{~km} / \mathrm{h}$, curve radius $1000 \mathrm{~m}$, wheel hardness $275 \mathrm{HB}$, rail hardness $300 \mathrm{HB}$. The life was described using the Weibull's distribution, which describes the lifetime distribution function by means of the equation [9]:

$$
F(t)=1-\exp \left[-\left(\frac{t}{\alpha}\right)^{\beta}\right],
$$

where $t$ is the locomotive mileage, $\alpha$ is the scale parameter, $\beta$ is the shape parameter.

The reliability function of the Weibull's distribution is described by means of the formula [9]:

$$
R(t)=\exp \left[-\left(\frac{t}{\alpha}\right)^{\beta}\right] .
$$

The parameters of the scale and shape of the Weibull's distributions for the life of the wheels due to flange and tread wear were determined using the least-squares method on the basis of estimations of the failure probability [9], consisting in achieving by the wheel of the admissible wear. The values of the coefficients $\alpha$ and $\beta$ of the Weibull's distribution and the square of the correlation $R^{2}$ between the lifetime distribution function described by the Weibull's distribution and the estimated values of probability of failure are provided in Table 3.

The amounts of the coefficient $R^{2}$ are high, therefore one can assume that the lifetime distribution functions and the reliability functions of the locomotive wheels described by the Weibull's distribution with the calculated $\alpha$ and $\beta$ coefficients.

\begin{tabular}{|c|c|c|c|}
\hline \multirow{2}{*}{ Distribution for } & \multicolumn{2}{|c|}{$\begin{array}{c}\text { Parameters of Weibull's } \\
\text { distribution }\end{array}$} & \multirow[t]{2}{*}{$R^{2}$} \\
\hline & $\alpha$ & $\beta$ & \\
\hline flange & 167553.5 & 4.454 & 0.948 \\
\hline wheel tread & 916139.9 & 5.504 & 0.962 \\
\hline
\end{tabular}

Table 3. Parameters of Weibull's distribution and $R^{2}$

The lifetime distribution functions $F(t)$ along with the estimated value of damage probability $F^{*}(t)$ is presented in Figures 13 and 14. The reliability functions of the wheels due to flange wear and tread are illustrated in Figures 15 and 16.

Flange lifetime distribution function

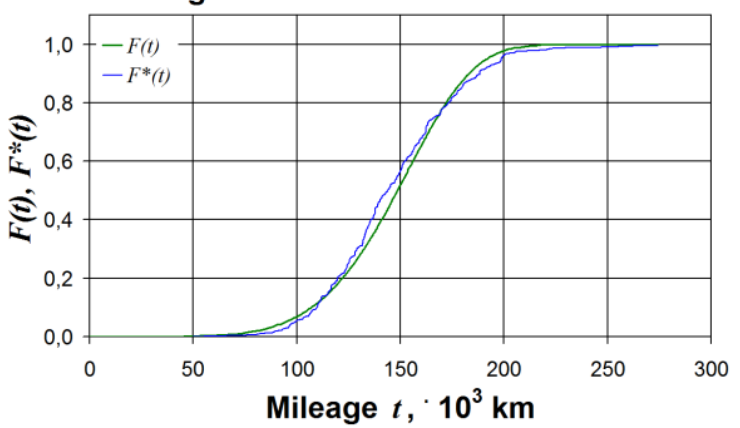

Fig. 13. The lifetime distribution function $F(t)$ along with the estimated value of probability $F^{*}(t)$ of achieving the admissible flange wear

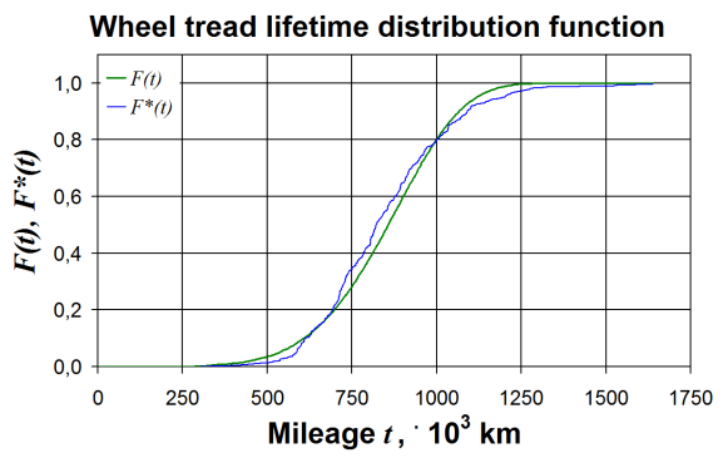

Fig. 14. The lifetime distribution function $F(t)$ along with the estimated value of probability $F^{*}(t)$ of achieving the admissible tread wear

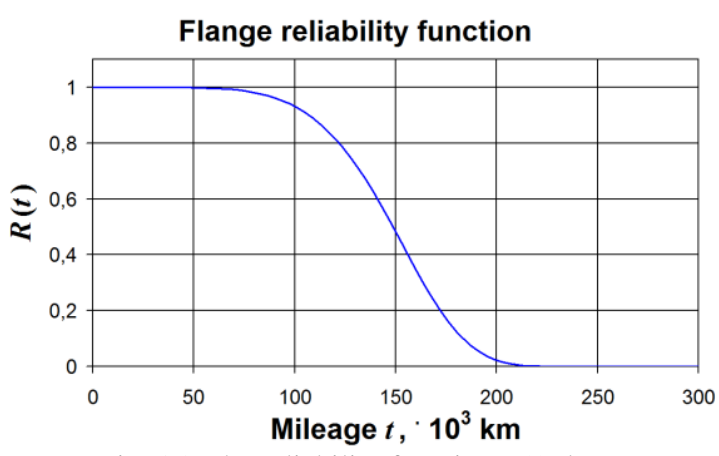

Fig. 15. The reliability function $R(t)$ due to achieving the admissible flange wear

It results from Figures 13 and 15 that the average life of the locomotives wheels of the discussed series due to flange wear for the assumed 
parameters of cooperation and hardness of wheels and rails is slightly less than $150000 \mathrm{~km}$ and for $90 \%$ of them it amounts from app. $100000 \mathrm{~km}$ to app. $200000 \mathrm{~km}$. As soon as the wheels achieve the admissible wear they are directed to reprofiling. For comparison, the wheels of the Chinese high-speed trains are reprofiled every $150000-250000 \mathrm{~km}$ [13]. Larger life of the high-speed trains wheels may result from the smaller axis pressure than in the freight locomotive and from the usage of the railroads of milder curves. The dispersion of life calculated from the model is close to the real one. It confirms the accuracy of the developed method of life and reliability modelling for the prognosis of the date limits of the repairs of wheels.

\section{Wheel tread reliability function}

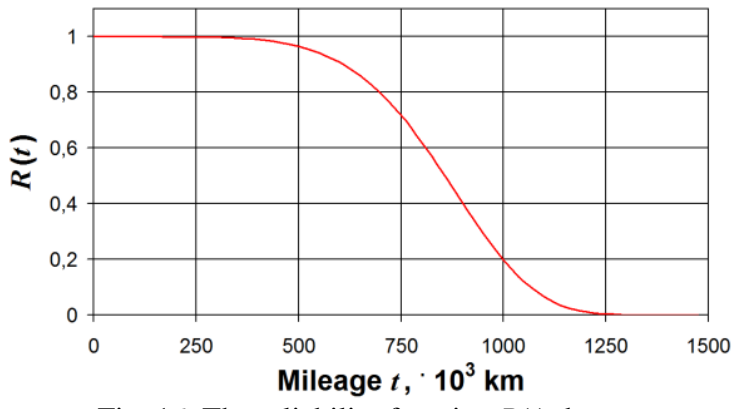

Fig. 16. The reliability function $R(t)$ due to achieving the admissible tread wear

The life of the wheels due to tread wear is significantly larger than for the flange wear (Figures 14 and 16). Its average value exceeds $800000 \mathrm{~km}$ and for $90 \%$ of the vehicles it is within the range from app. $500000 \mathrm{~km}$ to app. 1200000 $\mathrm{km}$. Therefore the achievement of the admissible tread wear is not the reason of wheels reprofiling.

\section{CONCLUSIONS}

The work developed the model of railroad wheels wear on the basis of the laboratory rollingsliding wear test results. The model was then used for calculation of durability and reliability of ET41 series electrical locomotives wheels. The obtained results allowed to state that the method of calculations presented in the article allows to determine the impact of various factors on the life of the wheels. The factors are: longitudinal creepage of the wheel on the rail, driving speed, curve radius, share of curves in the railroad, coefficient of friction between the wheel tread and rail, hardness of the material for the wheels and rails. Since the locomotive, chosen for the life and reliability of the wheels calculations, is an electric locomotive, its weight during usage is not subject to change. Therefore this factor has not been analysed in this work. However the presented method allows determination of the impact of the vehicle weight on the life of its wheels. It is of crucial importance e.g. in the case of freight wagons.

The most important parameters that impact the life of the wheels turned out to be:
- the longitudinal creepage of the tread on the rail - for life determined on the basis of the criterion of the admissible tread wear,

- share of the curves in the track length - for the flange wear.

The impact of the other factors on life is also significant. An interesting conclusion resulting from the calculations is that the hardness of wheels has a larger effect on their life than the hardness of rails upon which they move. The reliability of wheels was determined using the Monte Carlo method, which allows to take into consideration the randomness of the coefficients of the wear model. There is also a possibility to take into consideration the randomness of the parameters of cooperation of wheels and rails, similarly as in the work [13]. The obtained dispersion of life does not diverge from the actual one. It confirms accuracy of the calculations based on the model of wear for the prognosis of wheels life and therefore for planning of the date limits of their repairs. According to the authors of the works [17, 19] it allows to decrease the costs of vehicles maintenance, improve ride comfort and even safety thanks to prevention of derailment.

\section{REFERENCES}

1. Adamiec P, Witaszek K, Witaszek M. Service wear and durability of rail wheels. 12th International Colloquium Tribology. 2000 - Plus. Esslingen 11 13.01.2000: 1489-1494. German.

2. Boyacioglu P, Bevan A. Prediction of rail damage using a combination of Shakedown Map and wheelrail contact energy. Wear 2020; 460-461: 203457. https://doi.org/10.1016/j.wear.2020.203457.

3. Christoforou P, Fletcher DI, Lewis R. Benchmarking of premium rail material wear. Wear. 2019; 436-437: 202990. https://doi.org/10.1016/j.wear.2019.202990.

4. Ding HH, Fu ZK, Wang WJ, Guo J, Liu QY, Zhu $\mathrm{MH}$. Investigation on the effect of rotational speed on rolling wear and damage behaviors of wheel/rail materials. Wear 2015; 330-331: 563-570.

https://doi.org/10.1016/j.wear.2014.12.043.

5. Faccoli M, Petrogalli C, Lancini M, Ghidini A, Mazzù A. Effect of desert sand on wear and rolling contact fatigue behaviour of various railway wheel steels. Wear. 2018; 396-397: 46-161. https://doi.org/10.1016/j.wear.2017.05.012.

6. Granham JE, Beynon JH. Dry rolling -sliding wear of bainitic and pearlitic steels. Wear. 1992; 157: 81-109. https://doi.org/10.1016/0043-1648(92)90189-F.

7. Hu Y, Guo LC, Maiorino M, Liu JP, Ding HH, Lewis R, Meli E, Rindi A, Liu QY, Wang WJ. Comparison of wear and rolling contact fatigue behaviours of bainitic and pearlitic rails under various rollingsliding conditions, Wear. 2020; 460-461: 203455. https://doi.org/10.1016/j.wear.2020.203455.

8. Hu Y, Zhou L, Ding HH, Lewis R, Liu QY, Guo J, Wang WJ. Microstructure evolution of railway pearlitic wheel steels under rolling-sliding contact loading. Tribology International. 2021; 154: 106685. https://doi.org/10.1016/j.triboint.2020.106685. 
9. Jia X. Reliability analysis for Weibull distribution with homogeneous heavily censored data based on Bayesian and least-squares methods. Applied Mathematical Modelling. 2020; 83: 169-188. https://doi.org/10.1016/j.apm.2020.02.013.

10. Kamiński W. Comparison of selected railway lines in Poland using the Analytical Hierarchy Process method. Scientific Journal of Silesian University of Technology. Series Transport. 2020; 108: 73-84. https://doi.org/10.20858/sjsutst.2020.108.7.

11. Lesiak P, Sokołowski A, Wlazło M. Crosscorrelation function in identifying head checking defects of the railway rails. Diagnostyka. 2017; 18 (2): 65-7.

12. Li G, Hong $\mathrm{Z}$, Yan $\mathrm{Q}$. The influence of microstructure on the rolling contact fatigue of steel for high-speed-train wheel. Wear. 2015; 342-343: 349-355. https://doi.org/10.1016/j.wear.2015.10.002.

13. Luo R, Shi H, Teng W, Song Ch. Prediction of wheel profile wear and vehicle dynamics evolution considering stochastic parameters for high-speed train. Wear. 2017; 392-393: 126-138. https://doi.org/10.1016/j.wear.2017.09.019.

14. Maya-Johnson S, Felipe Santa J, Toro A. Dry and lubricated wear of rail steel under rolling contact fatigue - Wear mechanisms and crack growth. Wear 2017; 380-381: 240-250. https://doi.org/10.1016/j.wear.2017.03.025.

15. Mazzù A, Provezza L, Zani N, Petrogalli C, Ghidini A, Faccoli M. Effect of shoe braking on wear and fatigue damage of various railway wheel steels for high speed applications. Wear. 2019; 434-435: 203005. https://doi.org/10.1016/j.wear.2019.203005.

16. Mesaritis M, Shamsa M, Cuervo P, Santa JF, Toro A, Marshall MB, Lewis R. A laboratory demonstration of rail grinding and analysis of running roughness and wear. Wear. 2020; 456-457: 203379. https://doi.org/10.1016/j.wear.2020.203379.

17. Ramalho A. Wear modelling in rail-wheel contact. Wear 2015; 330-331: 524-532.

https://doi.org/10.1016/j.wear.2015.01.067.

18. Sęk J. Innovative technologies in low-emission transport. Scientific Journal of Silesian University of Technology. Series Transport. 2020; 107: 165-175. https://doi.org/10.20858/sjsutst.2020.107.12.

19. Shebani A, Iwnicki S. Prediction of wheel and rail wear under different contact conditions using artificial neural networks, Wear. 2018; 406-407: 173184. https://doi.org/10.1016/j.wear.2018.01.007.

20. Spangenberg U, Fröhling RD, Schalk Els PS. The effect of rolling contact fatigue mitigation measures on wheel wear and rail fatigue. Wear. 2018; 398-399: 56-68. https://doi.org/10.1016/j.wear.2017.11.012.

21. Stastniak P, Smetanka L, Drozdziel P. Computer aided simulation analysis for wear investigation of railway wheel running surface. Diagnostyka. 2019; 20 (3): 63-68. https://doi.org/10.29354/diag/11156.

22. Tressia G, Sinatora A, Goldenstein H, Masoumi M. Improvement in the wear resistance of a hypereutectoid rail via heat treatment. Wear 2020; 442-443: 203122. https://doi.org/10.1016/j.wear.2019.203122.

23. Urda $\mathrm{P}$, Aceituno JF, Muñoz S, Escalona JL. Artificial neural networks applied to the measurement of lateral wheel-rail contact force: A comparison with a harmonic cancellation method. Mechanism and Machine Theory. 2020; 153: 103968. https://doi.org/10.1016/j.mechmachtheory.2020.1039 68 .

24. Vira V, Kulyk V, Chepil R, Kharchenko Y, Duriagina $Z$. The diagnostics and ways heat treatment optimization of a railway wheels steel. Diagnostyka. 2019; 20 (2): 105-111. https://doi.org/10.29354/diag/10960.

25. Wang WJ, Lewis R, Yang B, Guo LC, Liu QY, Zhu $\mathrm{MH}$. Wear and damage transitions of wheel and rail materials under various contact conditions. Wear. 2016; 362-363: 146-152. https://doi.org/10.1016/j.wear.2016.05.021.

26. Wojciechowski Ł, Gapiński B, Firlik B, Mathia TG. Characteristics of tram wheel wear: Focus on mechanism identification and surface topography. Tribology International. 2020; 150: 106365. https://doi.org/10.1016/j.triboint.2020.106365.

27. Xia F, Cole C, Wolfs P. The dynamic wheel-rail contact stresses for wagon on various tracks. Wear. 2008; 265: 1549-1555. https://doi.org/10.1016/j.wear.2008.01.035.

28. Yazici O, Yilmaz S. Investigation of effect of various processing temperatures on abrasive wear behaviour of high power diode laser treated R260 grade rail steels. Tribology International. 2018; 119: 222-229.

https://doi.org/10.1016/j.triboint.2017.11.006.

29. Zhang Q, Toda-Caraballo I, Dai G, Feng Z, Li Q, $\mathrm{Yu}$ D. Influence of laminar plasma quenching on rolling contact fatigue behaviour of high-speed railway wheel steel. International Journal of Fatigue. 2020; 137: 105668. https://doi.org/10.1016/j.ijfatigue.2020.105668.

30. Zhou W, Abdulhakeem S, Fang C, Han T, Li G, Wua Y, Faisal Y. A new wayside method for measuring and evaluating wheel-rail contact forces and positions. Measurement. 2020; 166: 108244. https://doi.org/10.1016/j.measurement.2020.108244.

\section{Received 2020-07-20}

Accepted 2020-11-16

Available online 2020-11-17

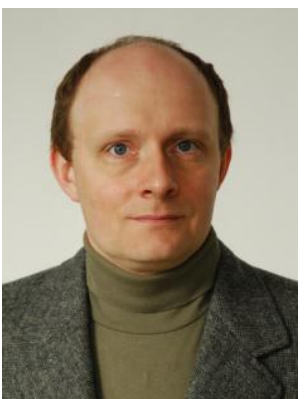

Mirosław WITASZEK obtained his Ph.D. degree at the Transport Department of the Silesian University of Technology in Katowice in the field of Machine Construction and Operation. His field of research - tribology, life and reliability of the elements of vehicles. 